\title{
Landlessness in Rural Areas of Pakistan and Policy Options: A Preliminary Investigation
}

\author{
Mohammad IRFAN and GhULAM Mohammad AriF*
}

\section{INTRODUCTION}

The quantification of landlessness is a formidable task. Conceptual ambiguities involved in the classification of landlessness and data limitations compound the difficulties in the estimation. Landlessness, which is an elusive concept, tends to acquire interpretations which vary with the objectives, context and estimation procedures adopted in different research endeavours. The denotation and connotation of the concept of landlessness, the population of interest (or at risk) and the objectives of measurement therefore need to be spelt out very clearly for a meaningful and policy-relevant exercise.

Identification of the state of landlessness using the criterion of ownership and access to land, has often been made. While the 'ownership' may be clear in certain contexts, that of 'access' needs further explanations in terms of the nature, extent and type of access. A related question, is the demarcation of the population or its subset whose landlessness is to be estimated: are all the inhabitants of an area or the ones who primarily depend on land for their livelihood be regarded as the relevant population. The dependence on land needs to be further specified whether the person is engaged in agricultural operations as worker or not.

Poverty, income or employment have often been the underlying objectives of the measurement of the landlessness. It must be noted that operationalization of these objectives in terms of distinct measurable entity is problematic. Concepts of economic holdings, work units and subsistence holdings are well-known. In Pakistan various efforts have been made to estimate underemployment in rural areas by specifying the land needed for full employment for a person or family. Research studies conducted by J. J. Stern (1981), S. M. Naseem (1981), ILO (1978), and Akmal Hussain (1988), can be cited as few examples. It must be noted that the search for ideal types, such as economic holdings, have been subjected to criticism by Myrdal (1968) among others, because they are static in nature. Furthermore, to the extent that the labour input per unit of land varies with the institutional

*The authors are Chief of research and Staff Economist respectively, at the Pakistan Institute of Development Economics, Islamabad. The authors are thankful to Mr Mohammad Rafique, Computer Programmer, for his computational work. 
arrangements as shown by Ishikawa (1978), the employment criterion which is used for establishing a size of holding can hardly be very precise. Moreover, the relationship between full employment and income or poverty status of an household remain unchecked. It is not precisely known whether or not the size of the holding under varying tenurial arrangements which affords full employment also yields subsistence income to the family engaged in agriculture. Efforts to translate the poverty line into land required under varying tenurial arrangements have been rather limited. The major objective of this exercise, however, is to estimate landlessness in relation to the subsistence income of the household.

\section{DEFINITIONS AND METHODOLOGY}

This exercise is confined to those who are primarily engaged in agriculture. The following two categories are particularly targeted:

(i) Pure Landless: A persons who are primarily working in agriculture but do not have access to land either as owners or as tenants. This simply implies landless labour who are employed as agricultural workers, or permanently hired workers as recorded in the Agriculture Censuses.

(ii) Near Landless: Persons or families engaged in agriculture having insufficient land to fulfill their needs.

Whilst the pure landlessness can be estimated from the data reported by the Agriculture Census, the estimation procedure for near landless involves certain assumptions. The following procedure has been adopted for measuring the landlessness for the Agriculture Census Year 1980.

1. Poverty line consistent with the nutritional needs ( 2550 calories per adult) constructed by Irfan and Amjad (1984) is updated for the Census Year 1980. In terms of March-July 1979, the time period of their study, Rs 1308 per capita was needed for adequate nutrition. The required per capita income for 1980 comes out to be Rs 1440 .

2. Average value added per cropped acre has been worked out by dividing the value added from Major and Minor Crops with the Cropped Area.

3. Average income for owner-operator households by different farm-size categories is estimated.

4. Livestock income for owner-operator households by different farm-size categories estimated by Faiz (1985) are added to arrive at the household and per capita income.

Using the above procedure the required cropped acreage yielding an income bare enough to meet the poverty line works out to be 6.2 acres for the owneroperator. In case of the owner/tenant category, the required cropped acreage is assumed to be 9.3 while for the tenants the same is 12.4 .

In principle, an estimate of landlessness, thus defined, can be made at country level. Given the well-known and wide inter-district productivity differentials, these estimates would be carrying an unknown margin of error. In order to reckon with this productivity variation, landlessness is worked out at the district level using the following additional steps:

1. A productivity index for each district has been constructed. This is simply a ratio of the income from Major and Minor crops from one cropped acre in the district to the average of the country.

2. Cropped acreage for subsistence income ūnder different tenurial arrangements in a given district has been worked out by adjusting the country level required area with the productivity index of the district.

3. Using the cropping intensity of the farm-size categories under different tenurial arrangements falling below the subsistence line, the cropped acreage has been converted to cultivated area. This was needed to estimate the landlessness among the associated households.

The estimation procedure above entails certain limitations; the major one being the estimation of income from livestock. Owing to the nonavailability of data at the district level, income from livestock is estimated by using the ratio it bears with the crop income at the country level. To the extent variations exist across districts and tenurial classes within the district, the landlessness may have been under or overestimated. It must also be noted that income from livestock accounts for a substantial portion of household income, particularly at the lower end of the land distribution. Hence, to an unknown extent livestock keeping constitutes a response to the landlessness.

\section{ESTIMATES OF LANDLESSNESS}

Using the above procedure the incidence of landlessness among the farm population, which consists of the owner-operator, owner/tenant, tenants and permanent hired workers as reported in the Agriculture Census 1980, is estimated. The permanent hired workers reported in the census were converted into pure landless households by dividing by 1.6 , the average earners per household in rural areas as reported in the Household Income and Expenditure Survey 1979.

The estimated landlessness (near landless and pure landless) provided in Table 1 reflects that nearly two-thirds of the farm households fail to meet their subsistence needs from the land at their disposal. Landlessness is highest ( 82 percent) in NWFP 
and lowest (52 percent) in Sindh province. In terms of the tenurial classification, tenants are the worst sufferers (72.2 percent) while the owner/tenant are subject to the lowest incidence (52.6 percent). Converted in numbers around 2.7 million farm households suffer from near or pure landlessness. The provincial distribution of these households indicates that 64 percent of the households are in the Punjab while 16 percent of the households are in the NWFP. The percentage shares of the landless households are 15.5 and 4.2 for Sindh and Balochistan respectively. The district-wise estimates of the landlessness are indicative of wide differentials. Within the same province of Punjab more than 90 percent of the farm households fall below the subsistence holding in rainfed districts like Rawalpindi, Attock and Jhelum. In contrast, less than one-half of the farm households suffer from landlessness in fertile districts like Rahim Yar Khan, Multan and Sahiwal. Similar differentials exist in the other three provinces.

Table 1

Near Landlessness and Pure Landlessness by Province 1980

(\% of Farm Household)

\begin{tabular}{|c|c|c|c|c|c|c|}
\hline \multirow{3}{*}{ Provinces } & \multicolumn{4}{|c|}{ Nearlandless } & \multirow[b]{2}{*}{ Pure } & \multirow[b]{3}{*}{ Total } \\
\hline & & Owner/ & & & & \\
\hline & Owner & Tenant & Tenant & All & Landless & \\
\hline Punjab & 60.2 & 55.4 & 70.9 & 61.7 & 6.3 & 68.0 \\
\hline Sindh & 33.5 & 20.7 & 71.1 & 49.3 & 3.2 & 52.5 \\
\hline NWFP & 83.5 & 61.5 & 80.3 & 79.6 & 2.4 & 82.0 \\
\hline Balochistan & 67.8 & 71.2 & 94.0 & 72.1 & 2.8 & 74.8 \\
\hline Pakistan & 60.6 & 52.6 & 72.2 & 62.0 & 5.1 & 67.1 \\
\hline
\end{tabular}

The distinction between the estimated landlessness and the incidence of poverty needs to be kept in mind. Poverty estimates are generally based on the actual household income which includes income from ex-village or non-farm labour market participation as part of the survival strategy of the household. Landlessness, on the other hand, in this study is estimated assuming only two sources of income, i.e. from crops and livestock. In a sense, this represents an effort to assess the possibilities of labour absorption consistent with subsistence income under the existing productivity conditions.

\section{POLICY OPTIONS}

The objective of improving this situation which is characterised by a very high level of landlessness can be achieved through various policy options. Broadly, the solution has to be sought either in the farm sector itself and/or in the non-farm sectors of the rural areas and in urban areas. Given the current emphasis on curtailing rural-urban migration flows, a preference has to be accorded to measures within the rural area, particularly, within the farm sector. In addition, within the farm sector one has to assume away the possibilities of transmigration from land-short or labour-abundant districts to the land-rich and scarcely populated districts. The assessment of the efficacy of the various measures is made below, wherein changes in tenancy regulations, land distribution and productivity growth in certain districts are taken as policy measures.

\section{(a) Let the Tiller of the Soil be the Owner}

Assuming that all the tenants and owner-cum-tenants become owner-operators, the effect of such a change on near landlessness is provided in Table 2. As shown in the table, the near landlessness category decreases from 62 percent to 49 percent in the country, a 21 percent decline. The largest impact on near landlessness is felt in Sindh province. Around 45 percent of the households cross the subsistence line. The impact of such a change in NWFP is meagre resulting in extricating only 6 percent of the households.

Table 2

Near Landless under Peasant Proprietorship and Existing Arrangements

\begin{tabular}{lccc}
\hline \multirow{2}{*}{ Provinces } & \multicolumn{2}{c}{ Percent of Household } & \\
\cline { 2 - 3 } & $\begin{array}{c}\text { Peasant } \\
\text { Proprietorship }\end{array}$ & Existing & (Percent Decline) \\
\hline Punjab & 49.75 & 61.7 & 19.4 \\
Sindh & 27.03 & 49.3 & 45.2 \\
NWFP & 74.29 & 79.6 & 6.7 \\
Balochistan & 65.11 & 72.1 & 10.0 \\
Pakistan & $\mathbf{4 9 . 2 4}$ & $\mathbf{6 2 . 0}$ & $\mathbf{2 0 . 6}$ \\
\hline
\end{tabular}

(b) Land Distribution

Under the land distribution scheme, owner-operator households belonging to the farm-size categories of 25 acres and above are permitted to have only 25 cultivated 
acres per household. The remaining area under their ownership is set aside for the distribution among the landless. To this is also added half of the area under ownercum-tenant categories belonging to the same size group. Land distribution is assumed to take place within the district.

The effect of the land distribution on landlessness varies with the choice of the rules governing distribution. If the objective is to minimize landlessness then priority should be given to those households which need small areas to qualify for subsistence land size. This may run counter to the equity considerations because those who need large areas to equal the subsistence requirement, the most needy would be neglected. Effect of landlessness in this paper is estimated using an average ratio of the area required for distribution to the area available in a district. This procedure may lead to a bias in the estimated impact on landlessness whose direction and magnitude would be specific to the decision rule.

As reflected by Table 3, the number of landless households declines from 2.7 to 1.7 million representing a 37.6 percent drop in the landlessness. The largest impact is felt in the Punjab and Sindh provinces whereas in the NWFP the change is not very significant.

Table 3

Effect of Land Distribution on Landlessness

\begin{tabular}{lccc}
\hline \multirow{2}{*}{ Provinces } & \multicolumn{2}{c}{ Landless Households (000) } & \\
\cline { 2 - 3 } & $\begin{array}{c}\text { Without } \\
\text { Distribution }\end{array}$ & $\begin{array}{c}\text { With } \\
\text { Distribution }\end{array}$ & Percent Change \\
\hline Punjab & 1744 & 1029 & -41.0 \\
NWFP & 446 & 413 & -7.4 \\
Sindh & 424 & 182 & -57.0 \\
Balochistan & 114 & 77 & -32.5 \\
Pakistan & 2728 & $\mathbf{1 7 0 1}$ & $\mathbf{3 7 . 6}$ \\
\hline
\end{tabular}

Underneath this aggregate picture lie tremendous inter-district variations. There are only 10 districts which can successfully meet the land requirement, under the above-mentioned scheme, to provide subsistence income to their landless households. Out of the remaining districts there are two groups: districts having above average and those with below average productivity. In order to have a significant impact on landlessness the ceiling of 25 acres per family has to be reduced in the districts having above average productivity. For the ones with below average productivity measures aimed at raising the level of productivity can improve the situation.

Under the assumption that the productivity of a district can be improved to attain the level of average productivity of the country the impact on near landlessness in selected districts has been estimated. As shown in Table 4, the near landlessness declines by 28 percent in these districts. It is interesting to note that this impact is roughly twice that of the land distribution in these districts.

Table 4

Effect of Productivity Increase on Near Landlessness in Selected Land Short and. below Average Productivity Districts

\begin{tabular}{lcccc}
\hline \multirow{2}{*}{ Provinces } & \multicolumn{3}{c}{ Near Landless Household (000) } & \\
\cline { 2 - 4 } & $\begin{array}{c}\text { No. of } \\
\text { District }\end{array}$ & $\begin{array}{c}\text { Prior to } \\
\text { Productivity } \\
\text { Increase }\end{array}$ & $\begin{array}{c}\text { After Productivity } \\
\text { Equal to Average } \\
\text { of the Country }\end{array}$ & Percent Decline \\
\hline Punjab & 6 & 744 & 529 & -29 \\
NWFP & 3 & 311 & 228 & -27 \\
Sindh & 1 & 85 & 66 & -23 \\
Balochistan & 3 & 66 & 53 & -20 \\
Pakistan & 13 & $\mathbf{1 2 0 6}$ & $\mathbf{8 7 6}$ & $\mathbf{2 8 . 4}$ \\
\hline
\end{tabular}

\section{CONCLUDING REMARKS}

Admittedly, the foregoing exercise is crude, entailing tremendous abstractions. However, there is definitely a need for further improvement of the results. An exercise embracing all the possible policy options has yet to be made. Notwithstanding these limitations, some of the findings are interesting as well as policy relevant.

In this study, the district has been taken as a unit of analysis. This is reflective of the concerns regarding rural-urban migration and the objective of providing subsistence to the people in the rural areas. The exercise has brought into sharp relief the tremendous diversities in the endowments and opportunities of the various districts. Whilst the magnitude of effort required to extricate the people from poverty and landlessness may be manageable in some areas in other areas the required policy measures and the entailed investment outlay is huge and the solution may be beyond the farm sector. The importance of district-specific land-ceilings for any land distribution measure can hardly be more emphasized.

In some of the areas, particularly the barani areas of Punjab, the hilly areas of 
NWFP and some of the districts of Balochistan, land distribution under the existing productivity conditions by itself may not be successful enough to keep the people engaged productively. These areas should be the obvious candidates for any federally administered poverty alleviation programme along with special rural development policies. Equally important, research should be carried out on the crops grown in these areas.

\section{REFERENCES}

Hussain, Akmal (1988). "Strategic Issues in Pakistan's Economic Policy". Lahore: Progressive Publishers.

Irfan Mohammad, and Rashid Amjad (1984). "Poverty in Rural Pakistan". In Azizur-Rehman and Eddy Lee (eds.), Poverty in Rural Asia. Geneva: ILO.

Ishikawa, W. (1978). "Labour Absorption in Asian Agriculture: Issues". Bangkok: Paper ILO/ARTEP.

Moahammad, Faiz, and Ghulam Badar (1985). "Structure of Rural Income in Pakistan: Some Preliminary Estimates". Pakistan Development Review. Vol. XXIV, Nos. 3 \& 4.

Myrdal, G. (1986). "Asian Drama”. London: The Penguin Press.

Naseem, S. M. (1981). "Underdevelopment, Poverty and Inequality in Pakistan". Lahore: Vanguard Publications.

Stern, J. J. Quoted in S. M. Naseem (1981).

Sinha, Radha (1984). "Landlessness: A Growing Problem". Rome: Food and Agriculture Organization of the United Nations.

Pakistan, Government of (1979). "Household Income and Expenditure Survey". Islamabad: Federal Bureau of Statistics, Statistics Division.

\section{Comments on}

"Landlessness in Rural Areas of Pakistan and Policy Options: A Preliminary Investigation"

The clamour for agrarian transformation in Pakistan has been going on for quite a long time and the literature dealing with the causes of underdevelopment of the agrarian structure along with policy prescriptions is well documented. Ifran and Arif's paper makes an important contribution to the existing literature by giving numerical estimates of landlessness at the aggregate (national and provincial) level as well as at the disaggregate (district) level. Their suggested policy measure of land reforms which include tenancy reform and redistribution of land, are also well supported by numerical estimates giving the percentage decline in landlessness under different policy options.

A general comment on the paper is that it does not give due attention to developing its position in relation to the existing literature on the agrarian structure of Pakistan. This, in my view is necessary in order for the reader to be convinced of the nature and extent of the contribution of the authors in the well-researched field of agrarian transformation.

Since the methodology forms an integral part of this paper it is my suggestion that it should be dealt with in a much more detailed and rigorous manner than it has been dealt with at present. That the methodology should be self-explanatory is specially important from the point of view of other prospective researchers who want to explore the specific area of estimation of landlessness in Pakistan. It is not absolutely clear from the paper as to how the authors use the information in the data base (the 1980 Agricultural Census of Pakistan) to arrive at their numerical estimates of landlessness. The regression procedure that has been employed to study the determinants of landlessness should either be discussed in a separate section or if the writers feel that it does not really belong in the paper then it should not be included at all.

Coming to the policy options section I would like to point out that since the policy prescriptions proposed by Irfan and Arif for attenuating the problem of landlessness have also been provided by others their specific contribution lies in the development of numerical estimates of decline in landlessness under changes in tenancy regulations and land redistribution, they should take a stronger stand on the specific choice of the policy option given that their results as presented in the paper support the relative efficacy of land redistribution over tenancy reforms. 
Also, the policy prescription of increasing productivity at the district level in accordance with the average level of productivity at the national level seems slightly contradictory given that the authors admit the existence of wide inter-district variations in landlessness which are to some extent a function of productivity differentials. I would also like to point out that even though the authors do not spell out the exact process of increasing productivity levels; agricultural productivity growth, the most outstanding feature of agricultural development is attained as proposed by Mellor through a combination of changes in the agrarian structure coupled with technological change and is therefore not an option which can be directly compared with the option of land redistribution.

Aliya H. Khan

Department of Economics, Quaid-i-Azam University, Islamabad 